\title{
UNDERSTANDING DIGITAL SOCIAL RESPONSIBILITY IN THE SOCIAL MEDIA CONTEXT: EVIDENCE FROM THAILAND
}

\section{AWilert Puriwat And BSuchart Tripopsakul}

\begin{tabular}{|c|c|}
\hline ARTICLE INFO & ABSTRACT \\
\hline $\begin{array}{l}\text { Article history: } \\
\text { Received } 17 \text { July } 2021 \\
\text { Accepted } 25 \text { October } 2021\end{array}$ & $\begin{array}{l}\text { Purpose: Organizations across the world consider social responsibility to be one of their } \\
\text { most important strategic obligations. In the digital era like nowadays, firms have } \\
\text { transformed social responsibility programs into digital platforms - digital social } \\
\text { responsibility (DSR). The purpose of this study is to see how DSR affects online word of } \\
\text { mouth (Online WOM) and purchasing intent(PI) in the setting of social media. } \\
\text { Methodology: Data were collected via an online survey among a sample of } 157 \text { students }\end{array}$ \\
\hline $\begin{array}{l}\text { Keywords: } \\
\text { Digital Social Responsibility, } \\
\text { Customer Perception and Behaviors, } \\
\text { Social Media, } \\
\text { University students. }\end{array}$ & $\begin{array}{l}\text { Findings: The findings revealed that customers' perceptions (CPN) and online WOM are } \\
\text { highly influenced by perceived DSR. CPN slightly mediated the link between DSR and } \\
\text { online WOM, and totally mediated the relationship between DSR and PI, according to the } \\
\text { mediation analysis. } \\
\text { Research, Practical \& Socialimplications: Our analysis verifies the influence of DSR on } \\
\text { customers' perceptions and online WOM, despite the fact that few previous studies have } \\
\text { looked into the impact of DSR on online WOM and PI. This empirical study can help } \\
\text { managers better gra sp the effects of DSR on consumer perceptions and online WOM via } \\
\text { socialmedia. } \\
\text { Originality: This study is a pioneering attempt to test the applicability of the DSR activities } \\
\text { in social media context on customer's perception and behavior. The findings should also } \\
\text { motivate businesses to conduct DSR activities in order to improve fa vorable consumer } \\
\text { perceptions and spread positive word of mouth about their businesses. }\end{array}$ \\
\hline & Doi: https://doi.org/10.26668/businessreview/2022.v7i1.257 \\
\hline
\end{tabular}

A Associate Professor and the Dean of Chulalongkorn Business School (CBS), Chulalongkorn University, Thailand. He holds the Doctor of Philosophy in management studies (D.Phil) from University of Oxford, UK, and the master's degree in private and public management, Yale University, USA. His research interests are in consumer behavior, digital social responsibility, and brand management and marketing. Email: wilert@cbs.chula.ac.th https://orcid.org/0000-0001-8891-3637

${ }^{B}$ Assistant Professor in the School of Entrepreneurship and Management (BUSEM) at Bangkok University. He received his Ph.D. in Technopreneurship and Innovation management and the M.Sc. in marketing from Chulalongkorn University, the Master of Management from Mahidol University, postgraduate diploma in management studies from University of Salford (UK), with a bachelor's degree in economics from Thammasat University, Thailand. His research interests are in entrepreneurship and innovation management, marketing management, and education development. Email: suchart.t@bu.ac.th https://orcid.org/0000-0002-8031-8056 


\title{
COMPRENSIÓN DE LA RESPONSABILIDAD SOCIAL DIGITAL EN EL CONTEXTO DE LAS REDES SOCIALES: EVIDENCIA DE TAILANDIA
}

\begin{abstract}
O
Propósito: Las organizaciones de todo el mundo consideran que la responsabilid ad social es una de sus obliga ciones estra tégicas más importantes. En la era digital como en la actualidad, las empresas han transformado los programas de responsabilidad social en plataformas digita les: responsabilidad social digital(DSR). El propósito de este estudio es ver cómo DSR a fecta el boca a boca en línea (Online WOM) y la intención de compra (PI)en el entorno de las redes sociales.
\end{abstract}

Metodología: Los datos se recopila ron mediante una encuesta en línea entre una muestra de 157 estudiantes de instituciones de educación superior en Tailandia. Las hipótesis propuestas fueron analizadas y evaluadas utilizando modelos de ecuaciones estructurales (SEM) en este estudio.

Hallazgos: Los ha llazgos revelaron que las percepciones de los clientes (CPN) y el WOM en línea están muy influencia dos por la percepción de DSR. CPN mediaba ligera mente el vínculo entre DSR y WOM en línea, y mediaba totalmente la rela ción entre DSR y PI, según el análisis de mediación.

Investigación, implicaciones prácticas y sociales: Nuestro análisis verifica la influencia de DSR en las percepciones de los clientes y WOM en línea, a pesar de que pocos estudios previos han analizado el impacto de DSR en WOM y PI en línea. Este estudio empírico puede ayudar a los gerentes a comprender m ejor los efectos de DSR en las percepciones de los consumidores y WOM en línea a tra vés de las redes sociales.

Originalidad: este estudio es un intento pionero de probar la aplicabilidad de las actividades de DSR en el contexto de las redes sociales en la percepción y el comportamiento del cliente. Los hallazgos también deberían motivar a las empresas a realizar actividades de DSR con el fin de mejorar las percepciones favorables de los consumidores y difundir el boca a boca positivo sobre sus negocios.

Palabras clave: Responsabilidad Social Digital, Percepción y Comportamientos del Cliente, Redes Sociales, Estudiantes Universitarios. 


\section{Introduction}

For corporations, social responsibility has been identified as one of the most important strategic movements. Positive relationships with consumers and other stakeholders can help businesses achieve an advantage. Businesses should use their legal or economic duties to help improve society (Carroll, 2016). Social responsibility is concerned with the long-term value of a company's interactions with a variety of stakeholders, including customers, shareholders, and employees. According to previous study (Back, \& Parks, 2003), social responsibility has an impact on a variety of customer attributes such as attitude, satisfaction, purchasing intent, and brand loyalty. Furthermore, social responsibility can increase corporate performance and reputation, as well as product assessments, allowing it to become a widely used marketing approach around the world.

Globally, advances in information and communication technology, as well as online social networking, have altered how people live and communicate. In comparison to traditional media, social media communication is more vivid and less expensive. In terms of technology, social media has enormous potential for expanding communication processes, increasing the participation of businesses and audiences in the program, and so enhancing direct interaction (Thackeray, Neiger, Hanson, \& McKenzie, 2008).

Individuals may have a chat, actively participate in conversations, get knowledge on current issues, and voice their view in a free and fair manner thanks to social networking services. Customers nowadays are endowed with advanced internet technology and mobile phones, which they use to express their ideas and effect change in their life. Furthermore, it aids in the delivery of critical information either on-demand or when others seek it (Fortunati, \& Taipale, 2014).

The Global Digital Report 2020, produced by We are Social (2020), provides more information regarding mobile technology and its adoption in Thailand. According to the survey, Thailand has 52 million mobile internet users out of a population of 70 million, implying a penetration rate of $75 \%$. According to the research, 52 million people utilize social media on the internet. Furthermore, a Thai user spends an average of 9 hours every day on the internet, with $97 \%$ of Thai internet users using mobile internet. Thailand leads the world in terms of internet banking service access, with $74 \%$ of the population, followed by Sweden (71\%) and Turkey (68\%). Facebook (93\%), YouTube (91\%), Line (84\%), Facebook Messenger (72\%), and Instagram (65\%) are the top five most active social media and messenger platforms accessed by internet users, according to a survey conducted among global users between the ages of 16 and 64 in the second and third quarters (Leesa-Nguansuk, 2019).

It is a well-known truth that DSR is a significant business strategy. However, according to previous studies, little study has been done on the impact of DSR on purchasing intent (PI), customer perception (CPN), and online word of mouth (online WOM). The current study aims to gain a comprehensive empirical understanding of the impact of DSR on CPN, online WOM, and PI via social media. Following the introduction, the current study article is divided into five sections, the first of which covers the literature on digital social responsibility (DSR), online WOM, and PI. The third section discusses the data collection approach used in the research. In the fourth section, the analysis' conclusions and key discoveries are discussed. In the fifth portion, the study concludes with a few recommendations for future researchers, while the sixth section discusses the limits and future research options. 


\section{Literature Review}

\subsection{Digital Social Responsibility (DSR)}

Social media platforms, such as Twitter, Facebook, and Instagram, which have exploded in popularity over the last decade, are a wonderful way for businesses to communicate with their customers and stakeholders (Kent, \& Taylor, 2016). As internet technology advances, historically offline corporate social responsibility projects and activities have been transformed into online and virtual corporate social responsibility - digital social responsibility (DSR). Previous research has shown that using social media can boost the effectiveness of CSR communication (Fernández, Hartmann, \& Apaolaza, 2021). Any undertakings, initiatives, or activities by an individual, group, or organization to undertake and implement a corporate social responsibility idea via online or through any digital platforms are referred to as digital social responsibility (DSR). In other words, DSR on social media can be described as the point at which customers begin to use social media to engage organizations in social responsibility communication. It also specifies consumer interaction with a company's social responsibility efforts via social media, such as Facebook likes, shares, and comments.

Organizations are finding that social networking sites are one of the most successful channels for implementing DSR (Colleoni, 2013). Organizations with a better CSR rating, according to Farzin and Fattahi (2018), are more likely to have an online presence, such as a larger number of Facebook page followers, than companies with a lower CSR rating. Furthermore, according to Tao and Wilson (2015), Facebook is the most popular social media platform for implementing digital social responsibility when compared to other social media platforms. Organizations of all sizes and sorts began relying significantly on this form of media to implement and convey their social responsibility in several ways (Colleoni, 2013). As a result of digital social responsibility projects and activities that are easily shared with the community, using social media to implement DSR improves the effectiveness of enterprises' social engagement. According to Fatma et al. (2020), the application of DSR through social media is expected to play a significant role in CSR concepts. DSR can be adopted at a faster rate and at a lesser expense than traditional media like as television, print, and radio.

\subsection{Consumers' Perception and Purchasing intent}

Customer perception is defined as a process by which consumers sense a marketing stimulus, and organize, interpret, and provide meaning to it (LaMarco, 2018). Previous research has found a link between customer perceptions and purchase intent in the context of social media (Khodabandeh, \& Lindh, 2021; Johnstone, \& Lindh, 2021). One can deduce a person's psychological tendencies as well as their likes and dislikes for an object based on their perception. A person's perception toward an object has the capacity to influence his or her judgment, information processing, and behavior. The findings of previous research revealed the existence of a link between a consumer's perception and their purchasing intent. Individuals with a positive perception are more likely to purchase a product, regardless of whether they like or dislike it.

Purchase intent is still an important metric for businesses (Anastasiadou, Lindh, \& Vasse, 2019). This is because businesses can estimate whether a customer would buy a product within a certain time frame. This variable also serves as a proxy for actual behavior (Cohen, Blake, \& Goodman, 2016). Consumers' purchasing decisions are influenced by social responsibility, according to Green and Peloza (2014), when a brand's products or services have ethical offerings, and the product demonstrates dedication to defend consumers' interests. According to Palacios-Florencio et al. (2018), one of the most crucial variables in a customer's buying decision is social responsibility initiative. 
According to Prendergast, Ko, \& Siu Yin (2010), online WOM has a direct impact on consumers' purchasing intent. It has an impact on a customer's trust in a company or its products. The unethical and deceptive practices of enterprises are assessed by the buyer when he or she decides to purchase, according to Palacios-Florencio et al. (2018). Customers expect businesses to have high morals, or they will avoid doing business with them. When DSR is applied, it has the potential to positively influence consumers' perceptions, resulting in good online WOM and, ultimately, influencing their purchase intent.

\subsection{Online word of mouth (Online WOM)}

The traditional concept of word of mouth (WOM) has evolved into online word of mouth (online WOM). Previous research has found a link between a company's social responsibility initiatives and positive word of mouth from customers (Jalilvand, Vosta, Mahyari, \& Pool, 2017). According to Du, Bhattacharya, and Sen (2010), one of the main behavioral outcomes in CSR activities is a consumer's readiness to speak favorably about a company that engages in social responsibility activities. A consumer demonstrates positive WOM, according to Yang (2017), if he or she prefers to share positive communication about a brand with others. WOM has an impact on a variety of factors, including awareness, behavior intention, actual purchase behavior (both offline and online), attitudes, and perceptions. Litvin, Goldsmith, and Pan (2018) define online WOM as an informal communication from a corporation addressed at customers via internet-based technology about product or service features. Hennig-Thurau, Walsh, and Walsh (2003) defined online WOM as any kind of message, whether favorable or negative, made by potential, real, or existing customers regarding goods or services and transmitted across to reach crowds of individuals and organizations using information and communications technology. In comparison to traditional offline WOM, online WOM via social media has several advantages, according to Fatma et al. (2020), such as rapid and spontaneous information transmission. It can also be used to build shared values for corporate social responsibility.

\section{Research Framework and Hypotheses Development}

After analyzing existing research in this area, we devised a research design to investigate the impact of DSR via social media on online WOM and purchase intent. The researcher presented eight theories, which are listed below. The proposed model for the research framework is shown in Figure 1. 


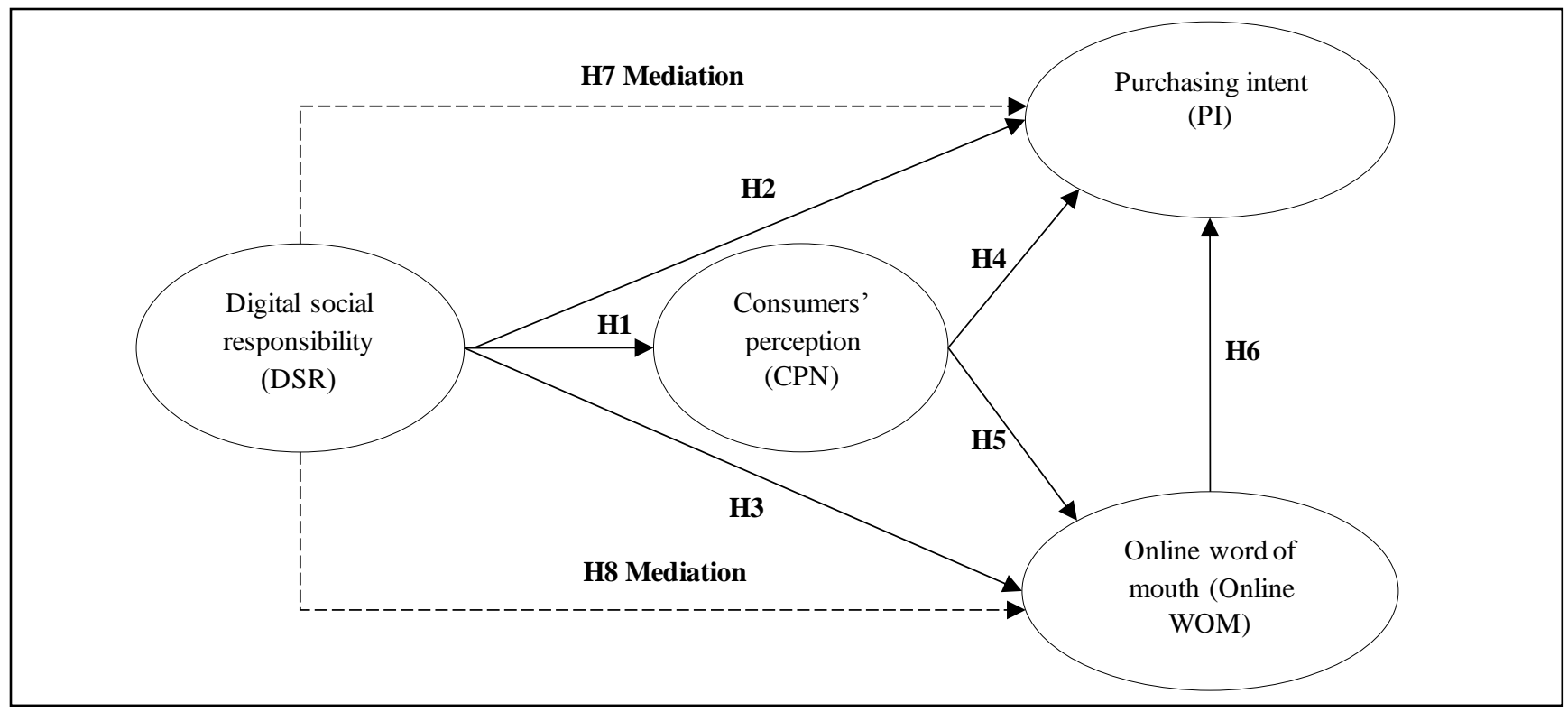

Fig. 1. The conceptual model

To examine the relationships among the model constructs, the following hypotheses have been developed:

H1: Consumer perceptions (CPN) are directly influenced by digital social responsibility (DSR) efforts. H2: Initiatives promoting digital social responsibility (DSR) have a direct impact on purchasing intent (PI).

H3: Initiatives promoting digital social responsibility (DSR) have a direct impact on online word of mouth (online WOM).

H4: Consumer perception (CPN) influences purchasing intent directly (PI).

H5: The perception of consumers (CPN) has a direct impact on online word of mouth (online WOM).

H6: Online word of mouth (online WOM) influences purchasing intent directly (PI).

H7: As mediated by customers' perceptions (CPN), digital social responsibility (DSR) has a strong positive indirect effect on purchasing intent (PI).

H8: As mediated by consumer perceptions (CPN), digital social responsibility (DSR) has a considerable positive indirect effect on online word of mouth (online WOM).

\section{Research Methodology}

\subsection{Research Design and Data Collection}

As previously stated, the purpose of this study is to investigate the impact of DSR on online WOM and buy intent in the setting of social media. To examine the presented hypotheses, the authors used a quantitative approach. DSR, customer sentiment, online WOM, and purchasing intent were all measured using a questionnaire. AMOS 22.0 was used to examine and analyze the data, evaluate the hypotheses given in the study, and assess the relevance of theories as well as positive correlation of variables using structural equation modeling (SEM). Purposive sampling was utilized to disseminate a self-administered online questionnaire to Thai Facebook users through Google Forms. Anderson and Gerbing (1988) advised a minimum sample size of 150 for a study. The authors aim for a minimum sample size of 150 in the data gathering process because SEM is the primary method employed in this study. The responders were initially checked using three questions in order to confirm the samples' eligibility. "Do you have a Facebook account that you have accessed in the previous month?" was the 
first question asked of the respondents. "Do you follow any company's official Fanpage on Facebook?" was the second question. "Have you ever seen any posts on Facebook specifically referring to the organization's contribution or granting of money to a charitable cause, volunteer efforts, or involvement in the communities in which it operates?" was the third question. Only those individuals who answered yes to all three initial screening questions were allowed to participate in the real poll, according to the researcher. On the basis of their perceptions of DSR initiatives on social media, participants were asked to recollect and amend their replies in the survey form. There were 163 surveys returned in all. A total of 157 legitimate surveys were utilized for further investigation after the completion of questionnaires was checked.

\subsection{Questionnaire development and pre-test analysis}

The questionnaires were divided into three sections: (1) preliminary screening questions, (2) general information on the study participants' demographic and behavioral characteristics, and (3) construct measurement items. Only measurement items from prior studies were used in this investigation. The items in the range of strongly disagree (1) to strongly agree (5) were measured using a five-point Likert scale (5). The suggested model's independent variable, DSR, was measured using a five-item scale derived from Butt (2016). The researcher used a four-item scale developed by Herrero, and Martnez (2020), and Chu, and Chen (2019) to assess the customer's perception. In the case of online WOM, measurements were taken using a four-item scale from the literature of Kwok et al. (2019) and Chu and Chen (2019). Purchasing intent was assessed using a three-item scale in Tien et al. (2019)'s study. Table 1 lists all of the scale items utilized in the study, which included a total of 16 items on the measuring scales.

To analyze the relevancy and validity of the questions, three researchers reviewed the content validity of the questionnaire during the pre-test stage. If the questions are acceptable, the item-objective congruence (IOC) index, first suggested by Rovinelli and Hambleton (1977) and mentioned by Turner and Carlson (2003), yields IOC values in the range of 0.67-1.00. Undergraduate students were engaged in a pilot research, and the data was utilized to examine the validity and understandability of the scale questions (Awang, 2015). Cronbach's alpha was used to determine the questionnaire's reliability, and it was found to be in the range of 0.7 or above for all variables, indicating that the questionnaire was reliable. See Table 1 for further information:

Table 1

The details of questionnaire constructs and questions

\begin{tabular}{|c|c|c|}
\hline Constructs & Items & $\begin{array}{c}\text { Observed Variables } \\
\end{array}$ \\
\hline \multirow{5}{*}{$\begin{array}{l}\text { Digital social } \\
\text { responsibility }\end{array}$} & DSR1 & Brand [NAME] has a solid digital social responsibility track record, in my opinion. \\
\hline & DSR2 & [NAME] is a brand with a digital social responsibility. \\
\hline & DSR3 & $\begin{array}{l}\text { In terms of societal challenges, brand [NAME] is making a concerted effort to implement DSR in } \\
\text { order to assist in the resolution of these difficulties. }\end{array}$ \\
\hline & DSR4 & $\begin{array}{l}\text { In terms of environmental challenges, brand [NAME] is making a concerted effort to use DSR to } \\
\text { inform customers about its environmental practices and protections. }\end{array}$ \\
\hline & DSR5 & $\begin{array}{l}\text { In terms of economic difficulties, brand [NAME] is making a concerted effort to implement DSR } \\
\text { in order to establish strong relationships with its customers and ensure its long-term economic } \\
\text { success. }\end{array}$ \\
\hline \multirow[t]{4}{*}{$\begin{array}{l}\text { Customers' } \\
\text { perception }\end{array}$} & CPN1 & $\begin{array}{l}\text { I believe that like, sharing, and commenting on [NAME]'s endeavors on social media sites is a } \\
\text { fantastic idea. }\end{array}$ \\
\hline & CPN2 & I like the notion of using social media to like, share, and comment on [NAME]'s initiatives. \\
\hline & CPN3 & On social media, like, sharing, and commenting on [NAME]'s projects appears fascinating. \\
\hline & CPN4 & My feelings regarding the brand [NAME] are positive. \\
\hline \multirow[t]{3}{*}{ Online WOM } & OWOM 1 & I'd "like" those DSR initiatives and messages from brand [NAME]. \\
\hline & OWOM 2 & I would "share" such DSR initiatives and messages from [NAME]. \\
\hline & OWOM 3 & I would "comment" on those DSR initiatives and messages from brand [NAME]. \\
\hline
\end{tabular}




\begin{tabular}{l|c|l}
\hline \multirow{2}{*}{$\begin{array}{l}\text { Purchasing } \\
\text { intent }\end{array}$} & OWOM 4 & On social media, I am likely to convey favorable word of mouth about brand [NAME]. \\
\cline { 2 - 3 } & PI1 & $\begin{array}{l}\text { I'd prefer buy items or brands that are involved in DSR initiatives than other (competing) products } \\
\text { or brands. }\end{array}$ \\
\cline { 2 - 3 } & PI2 & The next time I need something, I will buy something from [NAME]. \\
\hline
\end{tabular}

\section{Results}

\subsection{Sample Profile}

The data for this study was collected via an online self-administered questionnaire. The respondents were asked to recollect their most recent interaction with any organization's official Facebook Fanpage post that specifically mentioned the company's donation, charitable activity, volunteering, or community activities, regardless of where it was located. The respondents were then asked to complete the questionnaire based on their impressions of the DSR initiatives from the Facebook posts.

For additional processing, a total of 157 valid survey questionnaires were finalized. Table 2 shows the results, which show that males made up $44.5 \%$ of the total participants while females made up $55.5 \%$. The majority of the respondents spent 3-4 hours (40.5\%) per day on social media. Most respondents $(77.1 \%)$ believe that social media is a more convenient medium for participating in social responsibility activities than conventional media, and that businesses should use social media to engage stakeholders in solving social and environmental challenges $(86.2 \%)$.

Table 2

$\underline{\text { Respondent profiles }}$

\begin{tabular}{|c|c|c|c|}
\hline Variable & Item & Frequency & $(\%)$ \\
\hline \multirow[t]{2}{*}{ Gender } & Male & 70 & 44.5 \\
\hline & Female & 87 & 55.5 \\
\hline \multirow[t]{4}{*}{ Social media usage daily } & Less than 1 hour & 10 & 6.5 \\
\hline & 1 hour -2 hours & 31 & 19.8 \\
\hline & 3 hours -4 hours & 64 & 40.5 \\
\hline & More than 4 hours & 52 & 33.2 \\
\hline \multirow{3}{*}{$\begin{array}{l}\text { Is social media a more convenient platform than the traditional one for you to } \\
\text { participate in any social responsibility initiatives? }\end{array}$} & Yes & 121 & 77.1 \\
\hline & No & 12 & 7.6 \\
\hline & Maybe & 24 & 15.3 \\
\hline \multirow{3}{*}{$\begin{array}{l}\text { Do you believe businesses should use social media to engage stakeholders in } \\
\text { resolving social and environmental issues? }\end{array}$} & Yes & 135 & 86.2 \\
\hline & No & 8 & 4.9 \\
\hline & Maybe & 14 & 8.9 \\
\hline
\end{tabular}

Note: $\mathrm{N}=157$; missing data not shown and calculated in the table.

\subsection{Measurement Model}

Confirmatory factor analyses were used by the authors to investigate the relationship between each component and its retained item. In this estimation, the models were subjected to an overall goodness of fit test, as well as individual tests to determine their relevance in identifying the presumed relationship between the variables. There were four constructs and 16 individual items in the model. The most important indications of the measuring model utilized in this investigation are shown in Table 3. 
Table 3

Summary indicators of the measurement model

\begin{tabular}{|c|c|c|c|c|c|}
\hline Constructs and items & Loading & t-value & Alpha & Composite reliability & AVE \\
\hline Digital social responsibility & - & - & 0.829 & 0.923 & 0.578 \\
\hline DSR1 & 0.723 & - & - & - & - \\
\hline DSR2 & 0.734 & 13.112 & - & - & - \\
\hline DSR3 & 0.765 & 13.423 & - & - & - \\
\hline DSR4 & 0.801 & 15.123 & - & - & - \\
\hline DSR5 & 0.777 & 14.146 & - & - & - \\
\hline Customers' perception & - & - & 0.842 & 0.891 & 0.541 \\
\hline CPN1 & 0.745 & - & - & - & - \\
\hline CPN2 & 0.767 & 17.234 & - & - & - \\
\hline CPN3 & 0.709 & 14.897 & - & - & - \\
\hline CPN4 & 0.721 & 15.092 & - & - & - \\
\hline Online WOM & - & - & 0.838 & 0.914 & 0.600 \\
\hline OWOM1 & 0.751 & - & - & - & - \\
\hline OWOM 2 & 0.786 & 15.987 & - & - & - \\
\hline OWOM 3 & 0.762 & 15.763 & - & - & - \\
\hline OWOM 4 & 0.798 & 16.123 & - & - & - \\
\hline Purchasing intent & - & - & 0.853 & 0.875 & 0.571 \\
\hline PI1 & 0.756 & - & - & - & - \\
\hline PI2 & 0.762 & 16.092 & - & - & - \\
\hline $\mathrm{PI} 3$ & 0.748 & 15.872 & - & - & - \\
\hline
\end{tabular}

Cronbach's alpha values for all constructions and their subscales are in the range of 0.829 and 0.853 , as shown in Table 3. This value indicates how reliable the model's variables are. The internal coherence of the model's constructs was confirmed because all of the values were higher than the minimum level of 0.7 . The author also calculated the constructs' convergent and discriminant validities. The former validity is determined by three indices: composite reliability (CR), average variance extracted (AVE), and all factor loadings, with values greater than 0.7, 0.5, and 0.7, respectively (Awang, 2015). A high square root of AVE for each construct relative to correlation between that construct and other components in the study model is one of the criteria for sufficient discriminant validity. The square root of AVE for each construct $(\mathrm{DSR}=0.761 ; \mathrm{CPN}=0.736$; online $\mathrm{WOM}=0.774 ; \mathrm{PI}=0.755)$ is larger than the correlation between that construct and other constructs, according to the AVE computation. As a result, the discriminant validity of all notions is validated.

In terms of convergent and divergent validities, the results showed a satisfactory level of construct validity. This indicates that the study constructs are well-suited to evaluating the structural model. Chi-square $=199.383 ; \mathrm{df}=98 ; \mathrm{CMIN} / \mathrm{df}=2.035 ; \mathrm{GFI}=0.913 ; \mathrm{NFI}=0.917 ; \mathrm{TLI}=0.919 ; \mathrm{CFI}$ $=0.936 ;$ RMSEA $=0.035$ are the goodness-of-fit metrics for the measurement model above. For structural model analysis, these numbers indicated a satisfactory fit between the model and the data.

\subsection{Structural Model}

The structural model was evaluated by putting the suggested research model's hypotheses to the test. To determine the causal links between constructs, path analysis was used. Chi-square $=221.564 ; \mathrm{df}$ $=98 ; \mathrm{CMIN} / \mathrm{df}=2.261 ; \mathrm{GFI}=0.908 ; \mathrm{NFI}=0.907 ; \mathrm{TLI}=0.913 ; \mathrm{CFI}=0.914 ; \mathrm{RMSEA}=0.039$ were the goodness-of-fit metrics for this model. All of the indicators met the cutoff levels, implying that the model is a good fit. Table 4 displays a summary of hypothesis testing findings, revealing the relevance of correlations between variables. 
Table 4

Hypotheses testing

\begin{tabular}{|c|c|c|c|c|}
\hline Hypothesis & Path & Coefficient & t-value & Result \\
\hline $\begin{array}{l}\text { H1: Consumer perceptions (CPN) are directly influenced by } \\
\text { digital social responsibility (DSR) efforts. }\end{array}$ & $\mathrm{DSR} \rightarrow \mathrm{CPN}$ & 0.518 & 6781 & Supported \\
\hline $\begin{array}{l}\text { H2: Initiatives promoting digital social responsibility (DSR) } \\
\text { have a direct impact on purchasing intent (PI). }\end{array}$ & $\mathrm{DSR} \rightarrow \mathrm{PI}$ & 0.102 & 0.776 & Rejected \\
\hline $\begin{array}{l}\text { H3: Initiatives promoting digital social responsibility (DSR) } \\
\text { have a direct impact on online word of mouth (online WOM). }\end{array}$ & DSR $\rightarrow$ online WOM & 0.363 & 5.339 & Supported \\
\hline $\begin{array}{l}\text { H4: Consumer perception (CPN) influences purchasing intent } \\
\text { directly (PI). }\end{array}$ & $\mathrm{CPN} \rightarrow \mathrm{PI}$ & 0.356 & 5.228 & Supported \\
\hline $\begin{array}{l}\text { H5: The perception of consumers (CPN) has a direct impact } \\
\text { on online word of mouth (online WOM). }\end{array}$ & $\mathrm{CPN} \rightarrow$ online WOM & 0.439 & 4.575 & Supported \\
\hline $\begin{array}{l}\text { H6: Online word of mouth (online WOM) influences } \\
\text { purchasing intent directly (PI). }\end{array}$ & Online WOM $\rightarrow$ PI & 0.125 & 1.352 & Rejected \\
\hline
\end{tabular}

Notes: $* \mathrm{p}<0.05 ; * * \mathrm{p}<0.01 ; * * \mathrm{p}<0.001$.

DSR has a significant positive impact on CPN (Beta $=0.52 ; \mathrm{p}<0.001$; supporting $\mathrm{H} 1)$, online WOM $($ Beta $=0.36 ; \mathrm{p}<0.001$; supporting H3), but a non-significant impact on PI (Beta $=0.10$; rejecting $\mathrm{H} 2$ ), according to the regression results. Additionally, CPN has a significant positive impact on online WOM (Beta $=0.44 ; \mathrm{p}<0.001$; supporting H5) and PI (Beta $=0.36 ; \mathrm{p}<0.001$; supporting H4). Finally, the structural model results indicate that online WOM has no effect on PI (Beta $=0.13$; rejecting H6).

The bootstrapping methodology was used to investigate the mediating influence of DSR on online WOM and PI via CPN. DSR has a significant direct influence on online WOM $(0.363 ; \mathrm{p}<0.001$; $95 \%$ CI $[0.178,0.438])$ and a significant indirect effect on online WOM through CPN $(0.171 ; \mathrm{p}<0.001$; $95 \%$ CI [0.134, 0.304]), indicating that partial mediation is verified. DSR has a negligible direct influence on PI $(0.102$; $95 \%$ CI $[-0.111,0.085])$ but a significant indirect effect on PI through CPN $(0.202 ; \mathrm{p}<0.001 ; 95 \% \mathrm{CI}[0.138,0.304])$, according to the findings. As a result, the complete mediation effect has been established. The mediation analysis results using bootstrapping are summarized in Table 5.

Table 5

The results of mediation analysis

\begin{tabular}{c|l|c|c|c}
\hline \multicolumn{1}{c|}{ Hypothesis } & Direct effect & Indirect effect & Result \\
\hline $\mathrm{H} 7$ & $\mathrm{DSR} \rightarrow \mathrm{CPN} \rightarrow \mathrm{PI}$ & $0.102($ (n.s.) & $0.202(* * *)$ & Full Mediation \\
\hline $\mathrm{H} 8$ & $\mathrm{DSR} \rightarrow \mathrm{CPN} \rightarrow$ Online WOM & $0.363(* * *)$ & $0.171(* * *)$ & Partial Mediation \\
\hline Note: $* * *=\mathrm{p}<0.001 ; * *=\mathrm{p}<0.01 ; *=\mathrm{p}<0.05 ;$ n.s. $=$ "not significant"
\end{tabular}

\section{Discussion and Conclusion}

There are relatively few empirical studies that focus on digital social responsibility and its impact on customers' perceptions and behavior in a social media context. Social media has emerged as one of the most important platforms for businesses to interact with and engage customers in social responsibility concerns, projects, and activities. Despite the fact that DSR appears to be a critical strategic move for firms, academics have yet to fully comprehend the impact of DSR on customer perceptions, online WOM, and purchase intent. The current study looked at the impact of DSR on online WOM and buy intent, as well as the mediating role of consumers' perceptions in the relationship between DSR and online WOM and purchase intent. 
The current study found that DSR had a beneficial impact on customers' perceptions and online WOM, based on data collected from 157 samples from higher educational institutions in Thailand. The outcomes of this study support recent research by Fatma et al. (2020) that DSR activities can improve consumer sentiments and lead to good online WOM. DSR projects and activities can be used as a costeffective and time-effective platform for engaging stakeholders. Businesses should consider DSR as a strategic implementation option. Firms should, however, adopt a segmentation strategy to identify customers for DSR activities, and a traditional social responsibility method still plays a part in certain segmentation because not all customers have access to a digital platform. For practical purposes, DSR can be seen as a marketing activity that can help businesses develop favorable brand advocacy. Advocacy via social media appears to be a promising medium for disseminating information. It is made up of third-party cheerleaders, or brand ad vocates, who assist organizations promote themselves through their own social media channels. Firms can acquire brand advocacy with DSR by having Facebook users or Fanpage followers like, comment on, and share their DSR activities.

Practitioners will benefit from the findings of this study. Businesses must first recognize that increasing favorable customer perceptions and establishing positive online WOM may be accomplished through DSR efforts and investments. DSR appears to be a more successful method of encouraging favorable customer sentiments and word-of-mouth. Customers can participate in and involve themselves in social responsibility activities through digital channels such as social media, which are far more convenient and time-consuming than traditional ones. Businesses will face a difficulty in designing both complete online and offline social responsibility programs to satisfy their stakeholders and generate a competitive edge as social media technology advances.

\section{Limitation and Further Research}

The study set out to improve people's knowledge of DSR in the context of social media. There are a few drawbacks to the study that need to be addressed. Our research initially focused on the impact of digital social responsibility through social media, with Facebook serving as a representation of social networking sites (SNSs). More research may be done to see how DSR programs and activities affect online WOM and purchase intent on other social media platforms such Twitter, YouTube, Instagram, Tumblr, Flickr, Google+, Pinterest, and others. Second, the current study only looked at a few of the constructions that are thought to be affected by DSR. Other constructs such as customer loyalty, brand equity, and brand image could be included in future research and tested with empirical data. The third point to mention is that the samples were taken in Thailand. The results should be extra cautiously generalized. Customers' perceptions of DSR may be influenced by cultural factors. Further research could include data gathering and comparison across countries.

\section{References}

Abzari, M., Ghassemi, R. A., \& Vosta, L. N. (2014). Analysing the effect of social media on brand attitude and purchase intention: The case of Iran Khodro Company. Procedia-Social and Behavioral Sciences, 143, 822-826. https://doi.org/10.1016/j.sbspro.2014.07.483

Anastasiadou, E., Lindh, C., \& Vasse, T. (2019). Are consumers international? A study of CSR, crossborder shopping, commitment and purchase intent among online consumers. Journal of Global Marketing, 32(4), 239-254. https://doi.org/10.1080/08911762.2018.1528652 
Anderson, J. C., \& Gerbing, D. W. (1988). Structural equation modeling in practice: A review and recommended two-step approach. Psychological Bulletin, 103(3), 411. http://dx.doi.org/10.1037/0033-2909.103.3.411

Awang, Z. (2015). SEM made simple: A gentle approach to learning Structural Equation Modeling. Selangor, Malaysia: MPWS Rich Publication.

Back, K. J., \& Parks, S. C. (2003). A brand loyalty model involving cognitive, affective, and conative brand loyalty and customer satisfaction. Journal of hospitality \& tourism research, 27(4), 419435. https://doi.org/10.1177/10963480030274003

Butt, I. (2016). Corporate social responsibility and consumer buying behavior in emerging market: A mixed method study. International Journal of Business and Management, 11(7), 211. https://doi.org/10.5539/ijbm.v11n7p211

Carroll, A. B. (2016). Carroll's pyramid of CSR: taking another look. International journal of corporate social responsibility, 1(1), 1-8. https://doi.org/10.1186/s40991-016-0004-6

Chu, S. C., \& Chen, H. T. (2019). Impact of consumers' corporate social responsibility-related activities in social media on brand attitude, electronic word-of-mouth intention, and purchase intention: A study of Chinese consumer behavior. Journal of Consumer Behaviour, 18(6), 453462. https://doi.org/10.1002/cb.1784

Cohen, G., Blake, R. S., \& Goodman, D. (2016). Does turnover intention matter? Evaluating the usefulness of turnover intention rate as a predictor of actual turnover rate. Review of Public Personnel Administration, 36(3), 240-263. https://doi.org/10.1177/0734371X15581850

Colleoni, E. (2013). CSR communication strategies for organizational legitimacy in social media. Corporate Communications: an international journal, 18(2), 228-248. https://doi.org/10.1108/13563281311319508

Du, S., Bhattacharya, C. B., \& Sen, S. (2010). Maximizing business returns to corporate social responsibility (CSR): The role of CSR communication. International journal of management reviews, 12(1), 8-19. https://doi.org/10.1111/j.1468-2370.2009.00276.x

Du, S., \& Vieira, E. T. (2012). Striving for legitimacy through corporate social responsibility: Insights from oil companies. Journal of Business Ethics, 110(4), 413-427. https://doi.org/10.1007/s10551-012-1490-4

Farzin, M., \& Fattahi, M. (2018). eWOM through social networking sites and impact on purchase intention and brand image in Iran. Journal of Advances in Management Research. https://doi.org/10.1108/JAMR-05-2017-0062 
Fatma, M., Ruiz, A. P., Khan, I., \& Rahman, Z. (2020). The effect of CSR engagement on eWOM on social media. International Journal of Organizational Analysis. https://doi.org/10.1108/IJOA10-2019-1895

Fernández, P., Hartmann, P., \& Apaolaza, V. (2021). What drives CSR communication effectiveness on social media? A process-based theoretical framework and research agenda. International Journal of Advertising, 1-29. https://doi.org/10.1080/02650487.2021.1947016

Fortunati, L., \& Taipale, S. (2014). The advanced use of mobile phones in five E uropean countries. The British journal of sociology, 65(2), 317-337. https://doi.org/10.1111/1468-4446.12075

Green, T., \& Peloza, J. (2014). Finding the right shade of green: The effect of advertising appeal type on environmentally friendly consumption. Journal of Advertising, 43(2), 128-141. https://doi.org/10.1080/00913367.2013.834805

Hennig-Thurau, T., Walsh, G., \& Walsh, G. (2003). Electronic word-of-mouth: Motives for and consequences of reading customer articulations on the Internet. International journal of electronic commerce, 8(2), 51-74. https://doi.org/10.1080/10864415.2003.11044293

Herrero, A., \& Martínez, P. (2020). Determinants of electronic word-of-mouth on social networking sites about negative news on CSR. Journal of Business Ethics, 1-15. https://doi.org/10.1007/s10551-020-04466-9

Jalilvand, M. R., Vosta, L. N., Mahyari, H. K., \& Pool, J. K. (2017). Social responsibility influence on customer trust in hotels: mediating effects of reputation and word-of-mouth. Tourism Review. https://doi.org/10.1108/TR-09-2016-0037

Johnstone, L., \& Lindh, C. (2021, June). Online E-Communication Channels: The Impact of CSR and Reviews on Purchase Intent. In Digital Marketing \& eCommerce Conference (pp. 161-183). Springer, Cham.

Kent, M. L., \& Taylor, M. (2016). From Homo Economicus to Homo dialogicus: Rethinking social media use in CSR communication. Public relations review, 42(1), 60-67. https://doi.org/10.1016/j.pubrev.2015.11.003

Khodabandeh, A., \& Lindh, C. (2021). The importance of brands, commitment, and influencers on purchase intent in the context of online relationships. Australasian Marketing Journal, 29(2), 177-186.

Kwok, L., Mao, Z., \& Huang, Y. K. (2019). Consumers' electronic word-of-mouth behavioral intentions on Facebook: Does message type have an effect?. Tourism and Hospitality Research, 19(3), 296-307. https://doi.org/10.1177/1467358417742684

LaMarco, N. (2018, November 5). Consumer Perception Theory. https://smallbusiness.chron.com/consumer-perception-theory-40176.html 
Leesa-Nguansuk, S. (2019, February 19). Thailand Tops Global Digital Rankings. https://www.bangkokpost.com/tech/1631402/thailand-tops-global-digital-rankings

Litvin, S. W., Goldsmith, R. E., \& Pan, B. (2018). A retrospective view of electronic word-of-mouth in hospitality and tourism management. International Journal of Contemporary Hospitality Management. https://doi.org/10.1108/IJCHM-08-2016-0461

Palacios-Florencio, B., García del Junco, J., Castellanos-Verdugo, M., \& Rosa-Díaz, I. M. (2018). Trust as mediator of corporate social responsibility, image and loyalty in the hot el sector. Journal of Sustainable Tourism, 26(7), 1273-1289. https://doi.org/10.1080/09669582.2018.1447944

Prendergast, G., Ko, D., \& Siu Yin, V. Y. (2010). Online word of mouth and consumer purchase intentions. International journal of advertising, 29(5), 687-708.

Rovinelli, R. J., Hambleton, R. K. (1977). On the use of content specialists in the assessment of criterion-referenced test item validity. Dutch Journal for Educational Research, 2, 49-60

Tao, W., \& Wilson, C. (2015). Fortune 1000 communication strategies on Facebook and Twitter. Journal of Communication Management, 19(3), 208-223. https://doi.org/10.1108/JCOM-012013-0004

Thackeray, R., Neiger, B. L., Hanson, C. L., \& McKenzie, J. F. (2008). Enhancing promotional strategies within social marketing programs: use of Web 2.0 social media. Health promotion practice, 9(4), 338-343. https://doi.org/10.1177/1524839908325335

Tien, D. H., Rivas, A. A. A., \& Liao, Y. K. (2019). Examining the influence of customer-to-customer electronic word-of-mouth on purchase intention in social networking sites. Asia Pacific Management Review, 24(3), 238-249. https://doi.org/10.1016/j.apmrv.2018.06.003

Turner, R. C., \& Carlson, L. (2003). Indexes of item-objective congruence for multidimensional items. International journal of testing, 3(2), 163-171. https://doi.org/10.1207/S15327574IJT0302_5

We are Social. (2020). Digital in 2020: Global digital overview. https://wearesocial.com/digital-2020

Yang, F. X. (2017). Effects of restaurant satisfaction and knowledge sharing motivation on eWOM intentions: the moderating role of technology acceptance factors. Journal of Hospitality \& Tourism Research, 41(1), 93-127. https://doi.org/10.1177/1096348013515918 